\title{
New optical cell design for laser flash photolysis studies in supercritical fluids
}

\author{
Steven R. Goates \\ sgoates@byu.edu \\ Milton L. Lee \\ milton_lee@byu.edu \\ Qin Ji \\ Edward M. Eyring \\ Rudi van Eldik
}

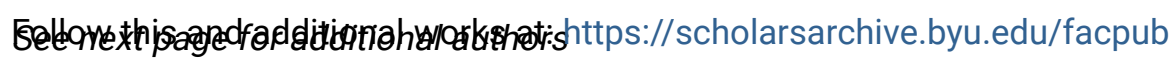

Part of the Biochemistry Commons, and the Chemistry Commons

\section{Original Publication Citation}

Ji, Qin, Edward M. Eyring, Rudi van Eldik, Kedika B. Reddy, Steven R. Goates, and MiltonÂ L. Lee."New optical cell design for laser flash photolysis studies in supercritical fluids." Review of Scientific Instruments 66 (1995): 222-226.

\section{BYU ScholarsArchive Citation}

Goates, Steven R.; Lee, Milton L.; Ji, Qin; Eyring, Edward M.; van Eldik, Rudi; and Reddy, Kedika Bal, "New optical cell design for laser flash photolysis studies in supercritical fluids" (1995). Faculty Publications. 690.

https://scholarsarchive.byu.edu/facpub/690

This Peer-Reviewed Article is brought to you for free and open access by BYU ScholarsArchive. It has been accepted for inclusion in Faculty Publications by an authorized administrator of BYU ScholarsArchive. For more information, please contact ellen_amatangelo@byu.edu. 
Authors

Steven R. Goates, Milton L. Lee, Qin Ji, Edward M. Eyring, Rudi van Eldik, and Kedika Bal Reddy 


\title{
New optical cell design for laser flash photolysis studies in supercritical fluids
}

\author{
Qin Ji, Edward M. Eyring, Rudi van Eldik, ${ }^{\text {a) }}$ and Kedika Bal Reddy \\ Department of Chemistry, University of Utah, Salt Lake City, Utah 84112 \\ Steven R. Goates and Milton L. Lee \\ Department of Chemistry, Brigham Young University, Provo, Utah 84602
}

(Received 7 September 1994; acceptcd for publication 3 October 1994)

\begin{abstract}
A high-pressure optical cell has been designed that achieves an effective separation between the chemical sample and the pressurizing medium and system. This design limits possible sample contamination and catalytic effects under supercritical fluid sample conditions. Laser flash photolysis experiments were carried out on molybdenum hexacarbonyl dissolved in supercritical $\mathrm{CO}_{2}$. The thermal ring closure reaction of the species $\mathrm{Mo}(\mathrm{CO})_{5} \mathrm{~L}$, where $\mathrm{L}$ is $2,2^{\prime}$-bipyridine was found to proceed at rates comparable to those measured previously in liquid benzene or toluene. Much larger activation volumes were found for the reaction in supercritical $\mathrm{CO}_{2}$ than in liquid toluene. (C) 1995 American Institute of Physics.
\end{abstract}

\section{INTRODUCTION}

Liquified gases and supercritical fluids (hereafter $\mathrm{SF}$ ) are presently recognized as unique reaction media for new chemistry in a wide range of thermal and photoinduced processes. ${ }^{1-10}$ Such media exhibit a remarkable temperature and pressure sensitivity that can cause dramatic changes in properties such as relative permittivity, diffusion characteristics, and solubility. ${ }^{1}$ It is especially the solute-solvent interactions that differ significantly from those prevailing in liquids at normal densities, such that these reaction media can be used simultaneously as solvent and reaction partner. ${ }^{1,10,11}$ For these reasons, the application of SF in extraction and other separation processes has been an active area of research and development in chemical process industries in recent years.

Poliakoff and co-workers ${ }^{10-12}$ were among the first groups to apply SF to the study of organometallic chemical reactions, because of the fundamental importance of these reactions in fields as diverse as industrial catalysis and biological processes. They have, in particular, studied photochemical reactions of organometallic species in supercritical $\mathrm{Xe}, \mathrm{CO}_{2}$, and $\mathrm{C}_{2} \mathrm{H}_{4} \cdot{ }^{12}$ We have in recent years developed an interest in the substitution behavior of metal carbonyl complexes, especially of reactive intermediates produced during flash photolysis of $\mathrm{M}(\mathrm{CO})_{6}(\mathrm{M}=\mathrm{Cr}, \mathrm{Mo}, \mathrm{W}) .{ }^{13-17}$ Since it is generally known that metal carbonyls are very sensitive to the presence of impurities and possible catalytic effects of metallic surfaces, it was essential to design an experimental procedure in which the investigated chemical system is in no direct contact with the pressurizing medium and system. Earlier work in the liquid phase included the use of a pillbox optical cell in order to separate the chemical system from the high-pressure medium and system. ${ }^{18}$ The optical cell design reported in the present paper permits an efficient separation of the SF sample system from the pressurizing medium and system.

\footnotetext{
a) On leave from the Institute for Inorganic Chemistry, University of Witten/ Herdccke, 58448 Witten, Germany.
}

\section{EXPERIMENTAL SECTION}

\section{A. Flash photolysis apparatus}

A schematic design of the pulsed laser flash photolysis apparatus is shown in Fig. 1. A Quanta Ray DCR-2 Nd:YAG laser sent a 6 ns laser pulse beam (about $100 \mathrm{~mJ} /$ pulse) at $\lambda=355 \mathrm{~nm}$ through the sapphire window of a high-pressure cell at $90^{\circ}$ from the path of the transient absorption probe beam. The detection system consisted of an Oriel $75 \mathrm{~W}$ Xenon lamp, a Durrum monochromator, and a Hamamatsu 1P28 photomultiplier tube (PMT). The voltage signal from the PMT was sent to a LeCroy 9400 oscilloscope interfaced (GPIB) to a 386-based computer (ARCHE DX-40). Data were analyzed by KINFIT software from OLIS (Bogart, GA).

\section{B. Pumping system}

The pumping system used in this study was based on a syringe-type system in which the fluid reservoir was the pump cylinder. A syringe-type pump was used because of the pulseless flow characteristics of this type of pump. The pumping system was modified from an ISCO 314 liquid delivery syringe pump. Basically, a pressure transducer and associated control electronics were added according to the work of Van Lenten and Rothman ${ }^{19}$ in order to provide for pressure control of the fluid instead of volumetric flow control. The full details, including electrical and mechanical drawings, of the modifications to the ISCO 314 pump can be found elsewhere. ${ }^{20}$ In addition, the pressure was monitored by a pressure transducer (SETRA 280E) with a pressure meter (DATUM 2000 ${ }^{\mathrm{TM}}$ ) which had been calibrated to an accuracy of $\pm 10 \mathrm{psi}\left(6.8 \times 10^{-2} \mathrm{MPa}\right)$.

\section{High-pressure cell}

The homemade high-pressure cell was machined from stainless steel, and contains four windows each of which is at $90^{\circ}$ to its neighbors (Fig. 2). Temperature was monitored by a temperature probe (Omega CF-000-RTD-4-60-2) which enters through one of the cell windows. The temperature probe 


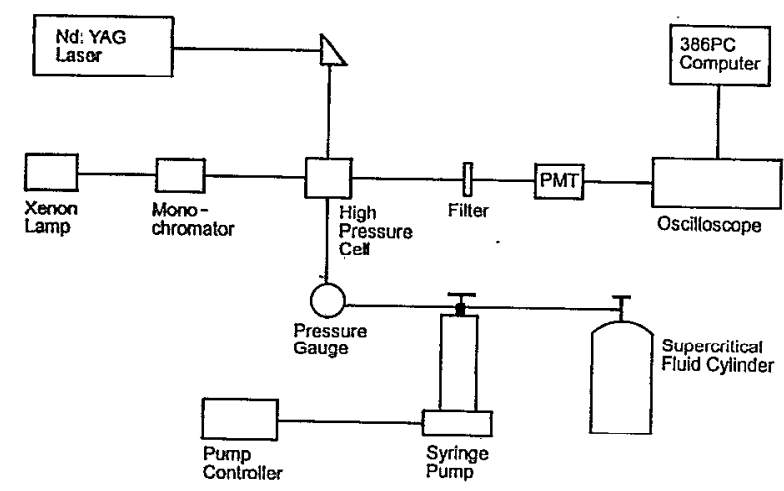

FIG. 1. Apparatus for laser flash photolysis studies in supercritical fiuid samples.

was calibrated against a mercury thermometer from the $\mathrm{Na}$ tional Bureau of Standards, and its accuracy is about $\pm 0.1^{\circ} \mathrm{C}$. The three optical windows were lined up to transmit the probe beam and the laser beam. On the top of the high-pressure cell, there was a three-way stainless-steel valve connected to the high-pressure pump and also to a pressure relief outlet (Fig. 3).

The diagram of the optical window is shown in Figs. 2 and 3. A Teflon delta ring and a silicone O-ring were used to seal the gap between the window and the high-pressure cell. A stainless-steel cap was used to hold a sapphire plate against the surface of the window plug. The sealing between the 10-mm-thick sapphire plate and the window plug depends on the smoothness of the plug surface in contact with the sapphire plate. The surface was carefully polished on a glass plate by hand to get a flat surface, using 1200,3000 ,

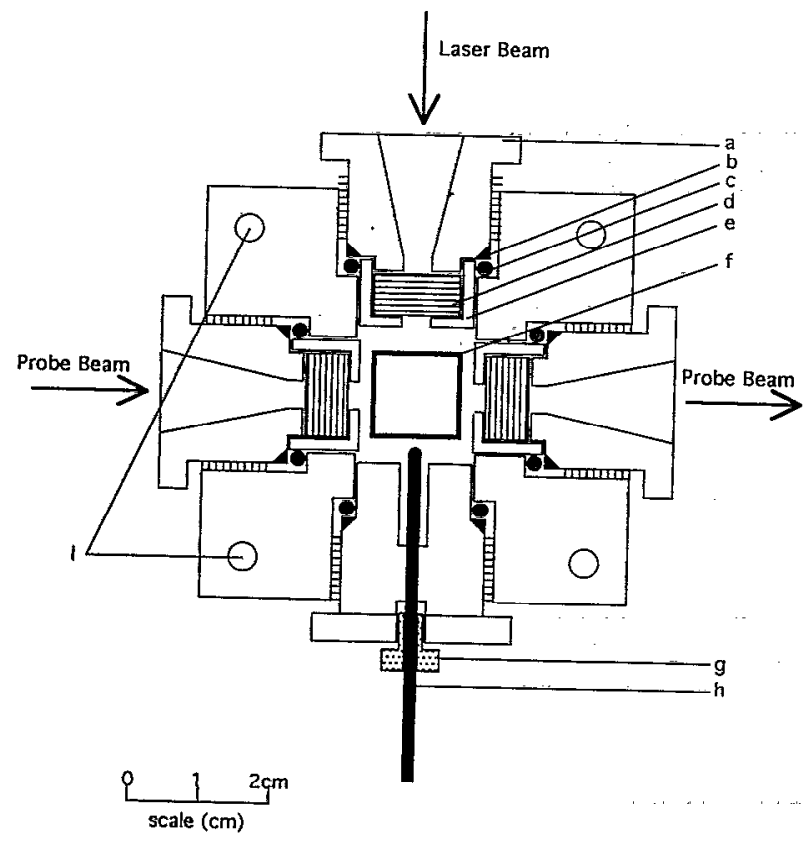

FIG. 2. Diagram of high-pressure cell (viewed from the top), (a) stainlesssteel window plug, (b) Teflon delta ring, (c) silicone O-ring, (d) sapphire plate, (e) stainless-steel cap, (f) quartz cuvette, (g) compression screw, (h) temperature probe, (i) water circulating path.

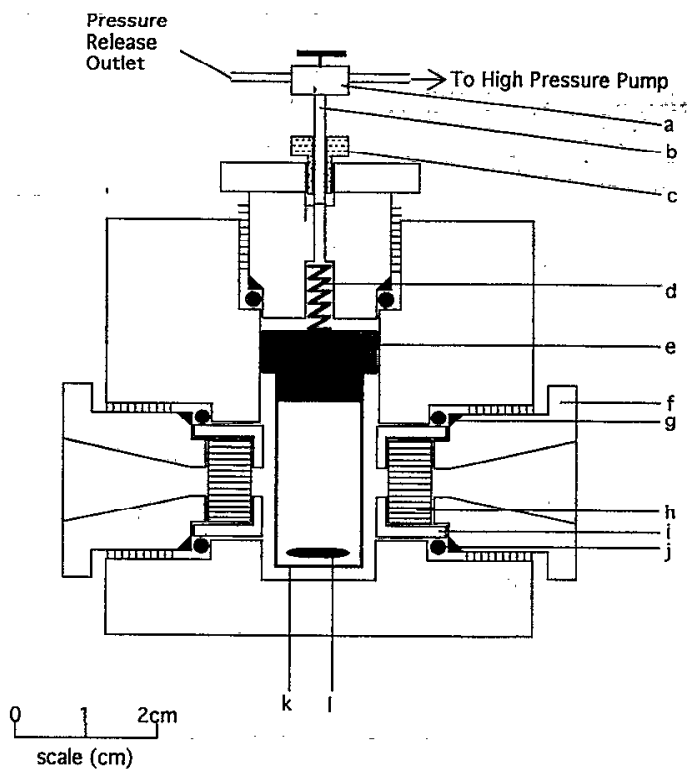

FIG. 3. Diagram of reactor structure (viewed from the side), a) stainlesssteel three-way valve, (b) $1 / 4$ in. stainless-steel tubing, (c) compression screw, (d) spring, (e) Teflon cap for the cuvette, (f) stainless-steel window plug, (g) Teflon delta ring, (h) sapphire plate, (i) stainlcss-stccl cap, (j) silicone O-ring, (k) quartz cuvette, (1) Teflon covered stirring bar.

$8000,14000,50000$, and 100000 mesh diamond grit, successively.

A major improvement in our experiments was the use of an isolated reaction cell inside the high-pressure cell to avoid any possible contamination and catalytic effects from the $\mathrm{O}$-rings and other cell components. The reaction cell consists of a homemade, square, quartz cuvette, and a specially designed Teflon cap (Fig. 4). The cuvette is $13.5 \mathrm{~mm} \times 13.5$ $\mathrm{mm} \times 25 \mathrm{~mm}$, and is fixed on a Teflon base inside the highpressure cell. The surface of the cuvette is $90^{\circ}$ to the laser beam to allow the laser beam to strike on an even surface, thus avoiding the observation of diffusion phenomena. A small, round quartz tube was used in earlier experiments, but because of the uneven scattering of the laser beam and the high diffusion coefficient of the SF, reproducible kinetic traces were very hard to obtain. A $40-50 \mathrm{~cm}$ long Teflon

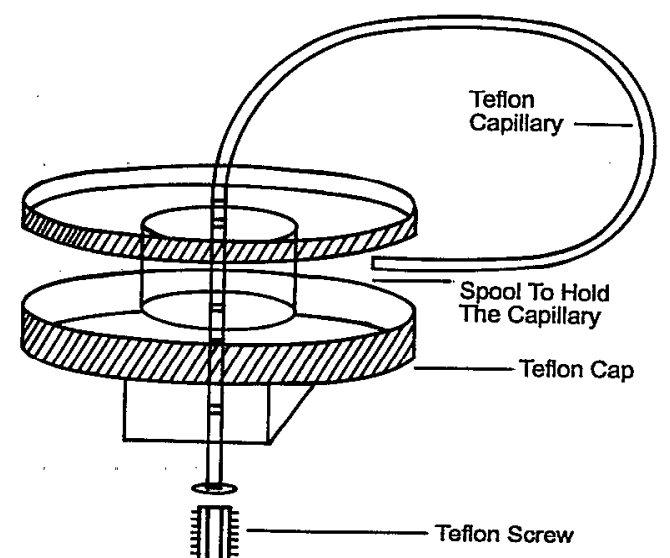

FIG. 4. Diagram of the cap of the cuvette. 
capillary tube (i.d. $=0.4 \mathrm{~mm}$ ) threaded through a hole in the center of the cap was uscd to control the diffusion of the reactants and to keep them inside the cuvette. One end of the capillary was melted with a heat gun, reshaped into a thin plate, and placed against the bottom of the cap. A small Teflon screw was used to fix this end inside the cap. The space around the cap was used to hold the capillary by winding the tube around the cap. This arrangement protected the reaction solution from contamination, and allowed us to stabilize reaction conditions and to obtain highly reproducible kinetic traces.

The high-pressure cell could also be mounted in the cell compartment of a Hcwlett Packard diode array spectrophotometer that enabled the recording of UV-VIS spectra during flash photolysis experiments.

\section{Procedures}

The $2,2^{\prime}$-bipyridine, pyridine, and molybdenum hexacarbonyl (98\%) used in this study were obtained from Aldrich. SFC grade carbon dioxide was purchased from Scott Specialty Gases. A mixture of the chemicals, along with a Teflon coated magnelic stirring bar, were placed in the quartz cuvette. After placing the cuvette inside the cell, the cell was filled with SFC grade carbon dioxide (at least three times) to eliminate any air from the high-pressure cell. Hot water was then circulated through the high-pressure cell wall to raise the temperature to $323 \mathrm{~K}$. Next, the high-pressure syringe pump was used to pressurize the cell to $10.3 \mathrm{MPa}$. The critical pressure and temperature of carbon dioxide are $7.5 \mathrm{MPa}$ and $304 \mathrm{~K}$, respectively. ${ }^{1}$ Before each laser pulse, a waiting period of $2 \mathrm{~min}$ was required to stabilize the reaction conditions after stopping the stirrer in order to obtain reproducible kinetic traces.

After a series of rate measurements, ice water was circulated through the cell wall to cool the cell down to $273 \mathrm{~K}$, during which supercritical $\mathrm{CO}_{2}$ was converted to the liquid phase. Then the pressure was released very slowly using the three-way valve. Because $\mathrm{CO}_{2}$ was vented as the headspace gas through the Teflon capillary, the reactants and products of the experiment remained in the cuvette instead of escaping to contaminate the whole high-pressure vessel.

\section{RESULTS AND DISCUSSION}

The advantage of the newly designed optical cuvette is the restriction of the chemical system to be investigated to a small reaction chamber $(\sim 1.3 \mathrm{~mL})$ within the pressure vessel. The long Teflon capillary allows flow of gaseous and liquid $\mathrm{CO}_{2}$ to the sample, but limits diffusion of the sample out of the cuvette to the pressure vessel. With the aid of the magnetic stirrer, it was possible to rapidly homogenize the reaction mixture in the SF phase between flash photolysis experiments.

In general, flash photolysis of $\mathrm{M}(\mathrm{CO})_{6}$ results in the loss of $\mathrm{CO}$ and the rapid formation of $\mathrm{M}(\mathrm{CO})_{5}$ (solvent). In the presence of a strong nucleophile $\mathrm{L}$, the coordinated solvent molecule will be displaced to produce $\mathrm{M}(\mathrm{CO})_{5} \mathrm{~L}$ as shown in Eq. (1). When $\mathrm{L}$ is a bidentate ligand, $\mathrm{M}(\mathrm{CO})_{5} \mathrm{~L}$ will undergo a subsequent thermal reaction to produce the ring-closed $\mathrm{M}(\mathrm{CO})_{4} \mathrm{~L}$ species as shown in Eq. (2).

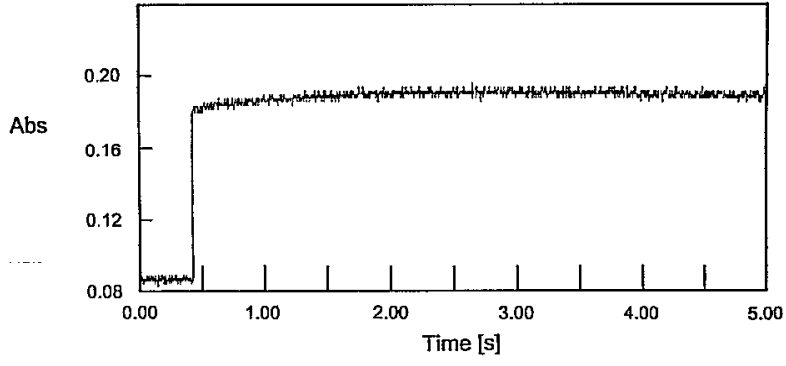

FIG. 5. A typical kinetic trace for the reaction of molybdenum hexacarbonyl with pyridine in $\mathrm{SF} \mathrm{CO}_{2}$ recorded at $390 \mathrm{~nm}, 323 \mathrm{~K}$, and $13.8 \mathrm{MPa}$.

$$
\begin{aligned}
& \mathrm{M}(\mathrm{CO})_{6} \stackrel{h v}{\rightarrow} \mathrm{M}(\mathrm{CO})_{5}+\mathrm{CO}, \\
& \mathrm{M}(\mathrm{CO})_{5}+\text { solv } \rightarrow \mathrm{Mast} \\
& \left.\mathrm{M}(\mathrm{CO})_{5} \text { (solv }\right), \\
& \mathrm{M}(\mathrm{CO})_{5}(\text { solv })+\mathrm{L} \stackrel{k_{1}}{\rightarrow} \mathrm{M}(\mathrm{CO})_{5} \mathrm{~L}+\text { solv, } \\
& \mathrm{M}(\mathrm{CO})_{5} \mathrm{~L} \stackrel{k_{2}}{\rightarrow} \mathrm{M}(\mathrm{CO})_{4} \mathrm{~L}+\mathrm{CO} .
\end{aligned}
$$

Our earlier work has shown that both reactions (1) and (2) strongly depend on the nature of the metal center $M$ and the nucleophile $\mathrm{L}$. Changes in $\mathrm{M}$ and $\mathrm{L}$ can result in a gradual change in the intimate nature of the substitution mechanism. ${ }^{13-17,21-25}$ The nature of the solvent controls the lability of the $\mathrm{M}(\mathrm{CO})_{5}$ (solv) species. With detailed mechanistic information available ${ }^{23-25}$ on these systems, we have now used these reactions to probe the usefulness of supercritical $\mathrm{CO}_{2}$ as a reaction medium for such reactions.

Flash photolysis of a mixture of $\mathrm{Mo}(\mathrm{CO})_{6}$ and pyridine (py) in supercritical $\mathrm{CO}_{2}$ resulted in a rapid increase in absorbance at $390 \mathrm{~nm}$, followed by almost no further change in absorbance at longer reaction times (see Fig. 5). When the $\mathrm{CO}_{2}$ pressure was increased from 10.2 to $23.8 \mathrm{MPa}$ no significant changes in the kinetic trace were observed. The coordination of py to the molybdenum carbonyl intermediate produced during flash photolysis is expected to be fast on the time scale of these experiments, based on kinetic data reported for this reaction in benzene, viz. $5.4 \times 10^{4} \mathrm{M}^{-1} \mathrm{~s}^{-1}$ at $24{ }^{\circ} \mathrm{C}^{26}$ Thus flash photolysis of mixtures of $\mathrm{Mo}(\mathrm{CO})_{6}$ and py in supercritical $\mathrm{CO}_{2}$ rapidly produces $\mathrm{Mo}(\mathrm{CO})_{5}$ py. The formation of this product was confirmed by the UV-VIS spectrum recorded after completion of the experiment and release of the $\mathrm{CO}_{2}$ pressure.

Similar reactions were studied using $2,2^{\prime}$-bipyridine (bipy) instead of py. The UV-VIS spectrum recorded immediately following the flash clearly indicates the formation of the ring-opened $\mathrm{Mo}(\mathrm{CO})_{5}$ bipy species $\left(\lambda_{\max }=390 \mathrm{~nm}\right.$ in benzene).$^{27}$ During the following few seconds, the spectrum changes to that for the ring-closed $\mathrm{Mo}(\mathrm{CO})_{4}$ bipy species. In this case, measurements at $490 \mathrm{~nm}$, the absorbance maximum reported for $\mathrm{Mo}(\mathrm{CO})_{4}$ bipy in benzene as solvent, ${ }^{27}$ showed well behaved first order traces (Fig. 6). Similar measurements at $390 \mathrm{~nm}$, corresponding to the absorbance maximum of $\mathrm{Mo}(\mathrm{CO})_{5} \mathrm{bipy},{ }^{27}$ showed an almost instantaneous absorbance increase followed by a subsequent slow increase due to the formation of ring-closed $\mathrm{Mo}(\mathrm{CO})_{4}$ bipy. Through- 

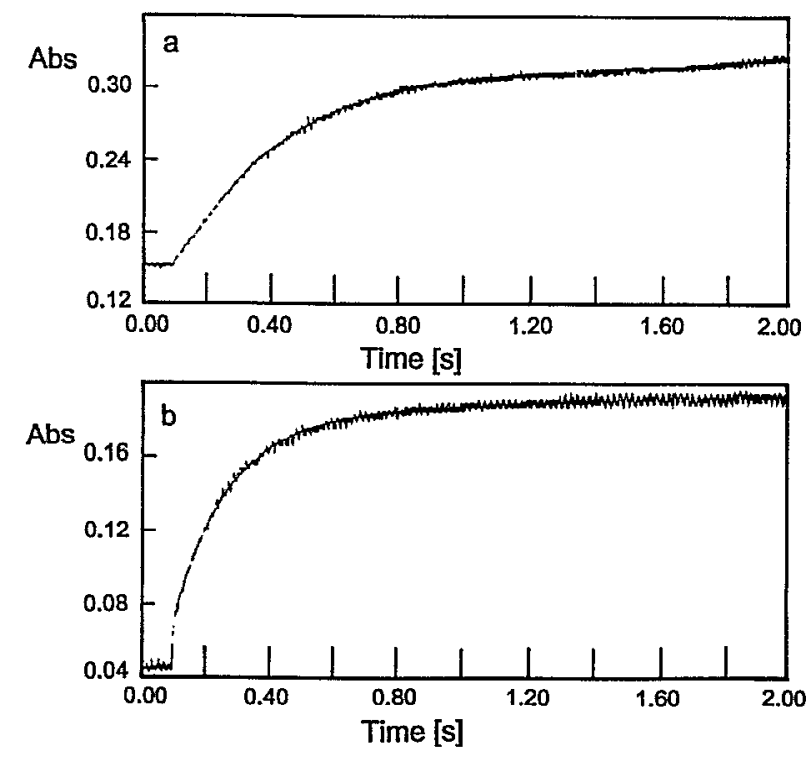

FIG. 6. Kinetic traces recorded at $490 \mathrm{~nm}$ for the reaction of $\mathrm{Mo}(\mathrm{CO})_{6}$ with bipyridine in $\mathrm{SF} \mathrm{CO}_{2}$ (a) $10.2 \mathrm{MPa}, 323 \mathrm{~K}$, (b) $23.8 \mathrm{MPa}, 323 \mathrm{~K}$.

out the series of measurements, the concentration of bipy had no effect on the observed first-order rate constant, in agreement with expectations for ring-closure reactions. Furthermore, the $k_{\text {obs }}$ value of $2.7 \pm 0.2 \mathrm{~s}^{-1}$ at $323 \mathrm{~K}$ and $10.2 \mathrm{MPa}$ is of the same order of magnitude as rate constants reported for this reaction in benzene and toluene. ${ }^{24,27}$ The reaction undergoes a remarkable acceleration on increasing the $\mathrm{CO}_{2}$ pressure as shown in Figs. 6 and 7. The results in Fig. 7 clearly indicate that the rate acceleration is largest close to the critical point, and decreases with increasing pressure. In terms of volumes of activation, the data correspond to a value of $-600 \mathrm{~cm}^{3} \mathrm{~mol}^{-1}$ in the low-pressure range and -79 $\mathrm{cm}^{3} \mathrm{~mol}^{-1}$ in the high-pressure range. Such a significant pressure dependence of the volume of activation must be related to the compressibility of the medium, which corre-

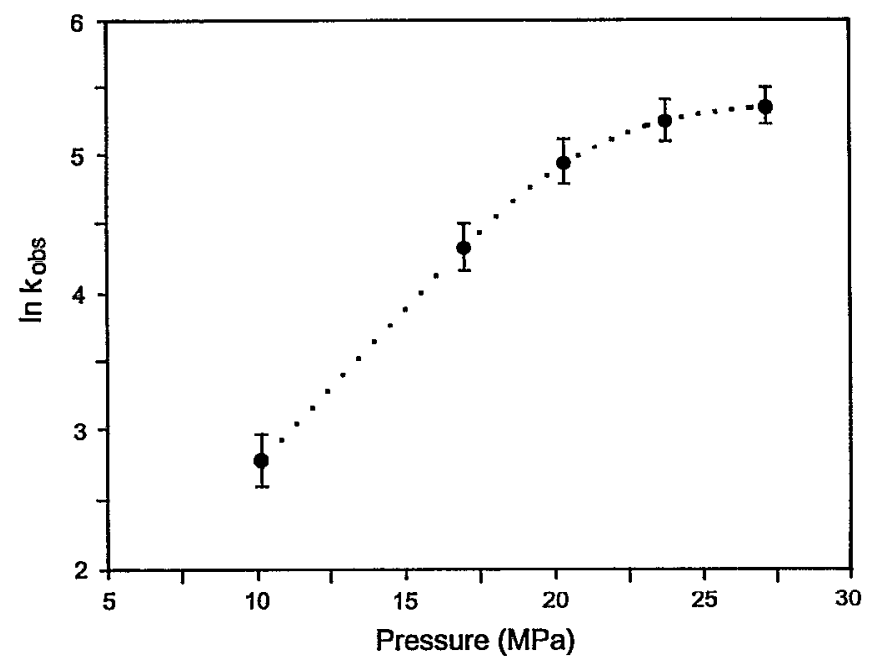

FIG. 7. Plot of $\ln k_{\mathrm{obs}}$ vs pressure for the ring-closure reaction of $\mathrm{Mo}(\mathrm{CO})_{5}$ bipy at $323 \mathrm{~K}$. The dots are experimental data. The dotted line is a smooth curve drawn between the experimental points. sponds to a low density, weak solvent at low pressure and a high density, stronger solvent at high pressure. Similar results have been reported for the decomposition of $\alpha$-chlorobenzylmethylether in supercritical 1,1difluoroethane and for the tautomeric equilibria of 2-hydroxypyridine, and 2-pyridone in supercritical 1,1-difluoroethane. ${ }^{28,29}$ The ring-closure reaction of $\mathrm{Mo}(\mathrm{CO})_{5}$ bipy is therefore accompanied by a large volume collapse at pressures close to the critical point where the medium is highly compressible. The effect is significantly smaller in the compressed SF medium where the obscrved activation volume resembles that observed in the liquid phase, viz. $-3.9 \pm 0.6 \mathrm{~cm}^{3} \mathrm{~mol}^{-1}$ in toluene. ${ }^{23}$ From these data it can be concluded that the ring-closure reaction is characterized by a highly ordered transition state.

The results of this investigation have clearly demonstrated how the new optical cell design can be used to perform routine kinetic investigations in supercritical fluids. The experimental data permit a direct comparison of the mechanistic behavior of metal carbonyl species in supercritical $\mathrm{CO}_{2}$ with mechanistic behavior in conventional organic solvents. An important observation is the extreme pressure sensitivity of the ring-closure reaction of $\mathrm{Mo}(\mathrm{CO})_{5}$ bipy which clearly demonstrates unique properties of this unconventional reaction medium.

\section{ACKNOWLEDGMENTS}

This work was funded by the Department of Energy, Office of Basic Energy Sciences (EME) and by the Volkswagen Foundation (RvE). The authors are indebted to Professor Keith P. Johnston for advice and encouragement and to Gabor Konya for help with several computer programs.

${ }^{1}$ (a) Supercritical Fluid Science and Technology, edited by K. P. Johnston and J. Penninger (ACS Symposium Series 406, American Chemical Society, Washington, D.C., 1989). (b) Supercritical Fluid Technology, Reviews in Modern Theory and Applications, edited by T. J. Bruno and J. F. Ely (CRC, Boca Raton, FL, 1991). (c) Supercritical Fluid Technology, edited by F. V. Bright and M. E. P. McNally (ACS Symposium Series 488, American Chemical Society, Washington, D.C., 1992). (d) Supercritical Fluid Engineering Science: Fundamentals and Applications, edited by E. Kiran and J. F. Brennecke (ACS Symposium Series 514, American Chemical Society, Washington, D.C., 1983).

${ }^{2}$ J. O. Metzger and B. Ondruschka, Nachr. Chem. Tcch. Lab. 38, 1169 (1990).

${ }^{3}$ R. W. Shaw, T. B. Brill, A. A. Clifford, C. A. Eckert, and E. U. Franck, Chem. Eng. News December 23, 26 (1991).

${ }^{4} \mathrm{~J}$. Zagrobelny, T. A. Betts, and F. V. Bright, J. Am. Chem. Soc. 114, 5249 (1992).

${ }^{5}$ J. Zagrobelny and F. V. Bright, J. Am. Chem. Soc. 114, 7821 (1992).

${ }^{6}$ T. A. Betts, J. Zagrobelny, and F. V. Bright, J. Am. Chem. Soc. 114, 8163 (1992).

${ }^{7}$ C. B. Roberts, J. E. Chateauneuf, and J. F. Brennecke, J. Am. Chem. Soc. 114, 8455 (1992)

${ }^{8}$ C. R. Roherts, J. Zhang, J. F. Brennecke, and J. E. Chateauneuf, J. Phys. Chem. 97, 5618 (1993).

${ }^{9}$ Y.-P. Sun and M. A. Fox, J. Phys. Chem. 97, 282 (1993).

${ }^{10}$ S. M. Howdlc, M. Poliakoff, and M. A. IIealy, J. Am. Chem. Soc. 112, 4804 (1990).

${ }^{11}$ M. Jobling, S. M. Howdle, M. Poliakoff, and M. A. Healy, J. Chem. Soc. Chem. Commun. 1990, 1287. 
${ }^{12}$ S. M. Howdle, M. Jobling, and M. Poliakoff, see Ref. 1(c), Chap. 10, pp. 121-131.

${ }^{13}$ S. Zhang, G. R. Dobson, H. C. Bajaj, V. Zang, and R. van Eldik, Inorg. Chem. 29, 3477 (1990). Organomet. Chem. 297, 279 (1990).

${ }^{14}$ S. Zhang, V. Zang, H. C. Bajaj, G. R. Dobson, and R. van Eldik, J. Organomet. Chem. 397, 279 (1990).

${ }^{15} \mathrm{~S}$. Weiland and R. van Eldik, Organometallics 10, 3110 (1991).

${ }^{16}$ V. Zang, S. Zhang, C. B. Dobson, G. R. Dobson, and R. van Eldik, Organometallics 11, 1154 (1992).

${ }^{17}$ S. Zhang, H. C. Bajaj, V. Zang, G. R. Dobson, and R. van Eldik, Organometallics 11, 3901 (1992).

${ }^{18}$ W. J. Le Noble and R. Schlott, Rev. Sci. Instrum. 47, 770 (1976).

${ }^{19}$ F. J. Van Lenten and L. D. Rothman, Anal. Chem. 48, 1430 (1976).

${ }^{20}$ J. C. Fieldsted, Ph.D. Dissertation, Brigham Young University, Provo, Utah, 1985, pp. 16-25.
${ }^{21}$ K. B. Reddy and R. van Eldik, Organometallics 9, 1418 (1990).

${ }^{22}$ S. Zhang, V. Zang, G. R. Dobson, and R. van Eldik, Inorg. Chem. 30, 355 (1991).

${ }^{23}$ K. B. Reddy, K. Hoffmann, G. Konya, R. van Eldik, and E. M. Eyring, Organometallics 11, 2319 (1992).

${ }^{24}$ K. B. Reddy, B. R. Brady, E. M. Eyring, and R. van Eldik, J. Organomet. Chem. 440, 113 (1992).

${ }^{25}$ S. Cao, K. B. Reddy, E. M. Eyring, and R. van Eldik, Organometallics 13, 91 (1994).

${ }^{26}$ S. Oishi, Organometallics 7, 1237 (1988).

${ }^{27}$ K. Kalayanasundaram, J. Phys. Chem. 92, 2219 (1988).

${ }^{28}$ K. P. Johnston and C. Haynes, AICHE J. 33, 2017 (1987).

${ }^{29}$ D. G. Pcck, A. J. Mehta, and K. P. Johnston, J. Phys. Chem. 93, 4297 (1989). 